
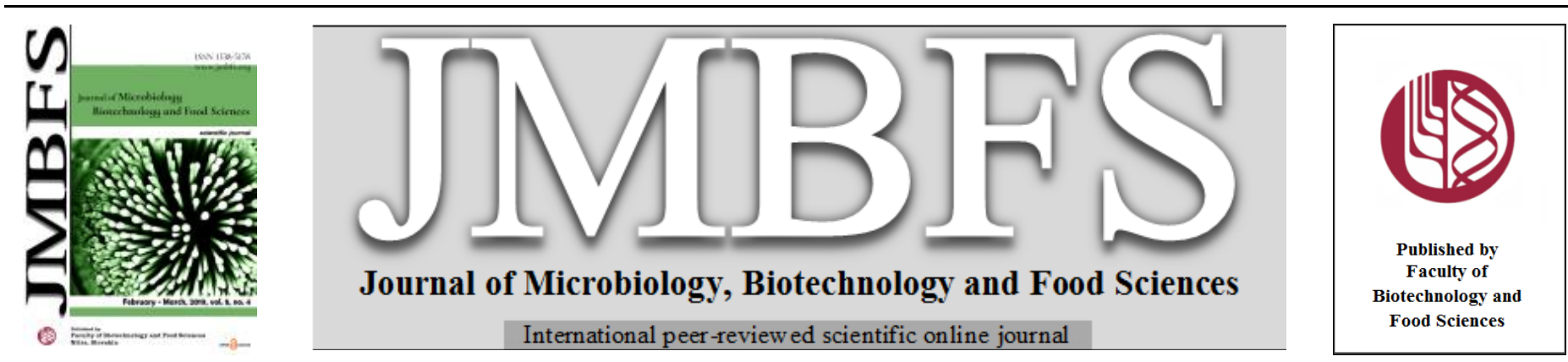

\title{
POTENTIAL EFFECT OF NATURAL PRODUCTS IN THE MANAGEMENT OF SEED INFESTATION OF CEREALS DURING STORAGE
}

\author{
Hanane Lougraimzi ${ }^{{ }^{*}}$, Abdelaaziz Bouaichi ${ }^{2}$, Soufiane M Sou ${ }^{3}$, Imad Kotba ${ }^{2}$, Mohamed Fadli ${ }^{\prime}$ \\ Address(es): \\ ${ }^{1}$ Laboratory of Nutrition, Health and Environment, Faculty of Sciences, Ibn Tofail University, Kenitra, Morocco. \\ ${ }^{2}$ Laboratory of Botany, Biotechnology and Plant Protection, Faculty of Sciences, Ibn Tofail University, Kenitra, Morocco. \\ ${ }^{3}$ Laboratory of Ecology and Environment and Applied Organic Chemistry Laboratory Faculty of Sciences Semlalia, University Cadi Ayyad, Marrakech, Morocco.
}

*Corresponding author: hanane.lougraimzi@uit.ac.ma

doi: 10.15414/jmbfs.2019.8.5.1161-1164

ARTICLE INFO

Received 15. 10. 2018

Revised 10. 12. 2018

Accepted 14. 12. 2018

Published 1. 4. 2019

Regular article

open $\partial_{\text {ACCESS }}$

\begin{abstract}
For stored cereals, pest protection methods are mainly based on the use of synthetic insecticides. However, in the face of the pollution and toxicity problems associated with these insecticides, the search for other alternative solutions is essential. It is within this framework that local natural products collected in the region of Gharb, Morocco have been used to: evaluate their insecticidal effect on Sitophilus granarius (L.) and Tribolium castaneum (Herbst) the main pests of the stored cereals, and test the effect of these natural products on the germination of soft wheat seeds. Before bioassays, a survey was conducted in three representative areas in the region of Gharb to advance our understanding on the type of methods commonly used by farmers to protect the stored cereals against different pest. During our investigation, we found that $91 \%$ of respondents favor the use of synthetic insecticides and only cereals intended for selfconsumption are treated with natural products. The results of the insecticidal effect of different natural products indicated that the highest mortality percentage was recorded with a concentration of $5 \%$ of Mentha pulegium powder and Capsicum frutescens. The former product induced $69 \%$ and $57 \%$ while the latter caused $36 \%$ and $22 \%$ mortality on the adults of S. granarius and T. castaneum, respectively. The germination test showed that these natural products have no effect on the germination rate of soft wheat grains. Therefore, these products can be potential alternative the synthetic insecticides for the protection of stored against pest infestation.
\end{abstract}

Keywords: Natural products, Synthetic insecticides, Stored cereals, Sitophilus granarius (L.), Tribolium castaneum (Herbst)

\section{INTRODUCTION}

Nowadays, food security becomes a challenging issue for many countries worldwide (Obeng-Ofori, 2011). This is not surprising given that the global population increased four fold during the last century, with current estimates placing it around 9.2 billion by 2050 and 11.5 billion by 2100 . Over $87 \%$ of this population lives in the developing countries of Africa, Asia, and Latin America (De Vries, 2001). As many other countries, Morocco is also required to meet food needs and significantly increase the food production by increasing the area cultivated, the introduction of new varieties, as well as the reduction of postharvest losses. Post-harvest losses in Africa are often estimated to be between 20 and 40\% (World Bank, 2011). Post-harvest losses in the developed countries are lower than in the developing countries because of the presence of high efficient farming systems and, better transport infrastructure, better good farm management, and effective storage and processing facilities that ensure a larger proportion of the harvested foods is delivered to the market in the most desired quality and safety (Abass et al., 2014). Seed storage, is a critical issue that needs special attention in order to meet the safety requirements of seeds after harvest and to ensure food security (Adjalian et al., 2014). In Morocco, the storage of cereals and legumes is increasingly exposed to pest damage. The insect infestations result in a drastic income loss of farmers who store their harvested produce in different structures that may be unsuitable for seed storage. Hodges (2012) also estimated quantitative grain losses to be in the range of 10 to $20 \%$, but losses of over $50 \%$ in cereals and up to $100 \%$ in pulses have been reported by other investigators (Obeng-Ofori, 2011; Abass, 2014).

The different actors (peasants, farmers, wholesalers, millers, etc.) favor the use of synthetic insecticides. The use of synthetic insecticides or fumigants are for the most part effective in optimal conditions against pests, but their intensive and uncontrolled use presents enormous disadvantages (Relinger et al., 1988; Haubruge et al., 1988). Many studies have exposed the problem of resistance of insect strains mainly due to the uncontrolled use of peasants (Benhalima et al., 2004; Ngamo \& Hance, 2007; Huignard et al., 2011). In addition, several reports have shown that cancerous pathologies were associated with the chronic exposure of different pesticides (Multigner, 2005; Gatignol \& Etienne, 2010). To overcome these problems, the search for alternative methods of pest control which are environment ally friendly are essential (Ouedraogo et al., 2016). Many studies are currently being developed to identify components extracted from plants that have insecticidal activity against stored product pests (Ngamo \& Hance, 2007 ; Guèye et al., 2011; Hedjal, 2014).

Botanical insecticides are natural compounds with insecticidal properties commonly used for crop protection (Grdiša \& Gršić, 2013). The first insecticide application of quassia date from 1880 and, it was successfully used against aphids (Pluke et al., 1999). These pesticide plants have been used for millennia and were widely promoted in commercial farming until the 1940s, when synthetic pesticides have been developed (Anjarwalla et al., 2016). The use of naturel products as insecticides is of most importance in nowadays farming because they are generally less harmful to beneficial insects and to environment (Amoabeng et al., 2013; Mkenda et al., 2015).

The overall goal of this study was to identify the appropriate methods to control the grains stored against different pests. In this study, a survey was conducted among farmers in the Gharb zone (north-west of Morocco), in order to quantify the rate of synthetic chemicals as well as to identify the natural protection methods used by the farmers, for storing local products. Specific objectives of this study were to: i) evaluate the effectiveness of selected naturel products against Sitophilus granarius (L.) and Tribolium castaneum (Herbst), and ii) Test their effect on the germination of wheat seeds.

\section{MATERIAL AND METHODS}

\section{Study area and data collection}

The study area is localed in the north-west part of Morocco with latitude between $34^{\circ} \mathrm{N}$ and $35^{\circ} \mathrm{N}$ and longitude between $5.5^{\circ} \mathrm{W}$ and $6.7^{\circ} \mathrm{W}$ and elevation until 26 $\mathrm{m}$ above the sea level. This area occupies a special place as the main producer of cereals and pulses nationwide. The survey prepared was composed of many questions related to different modes and natural products used by the peasants for 
storing their produce. For a better representation of the region, 300 people were selected in the three provinces of the study area namely: Kenitra, Sidi Slimane, Sidi Kacem.

\section{Collection and preparation of natural products}

Samples of both plants: Mentha pulegium and Glycyrriza foetida were collected between May and July 2013 in northwestern Morocco (the Gharb area). The plants were identified at the Biodiversity and Natural Substances Laboratory of the University Ibn Tofail of Kenitra-Morocco. In addition, Capsicum frutescens, Allium sativum, Urginea maritima and rock salt were purchased at the loca market (Gharb Souk Had). Once these products were air-dried, protected from heat and light for four weeks, they were stored in plastic bags at a temperature of $4^{\circ} \mathrm{C}$. Before each test, these products were milled using a coffee grinder to obtain a powder.

\section{Insects tested}

Bioassays were conducted to study the insecticidal effect of various natural products against adults of Sitophilus granarius (L.) and Tribolium castaneum (Herbst). Both insects were reared in laboratory conditions $\left(27 \pm 1^{\circ} \mathrm{C}, 70 \pm 5 \%\right.$ $\mathrm{RH})$ during a one-year period and respectively reared on whole wheat.

\section{Contact toxicity of seeds treated with natural products}

Concentrations of $1 \%, 2 \%$ and $5 \%(\mathrm{w} / \mathrm{w})$ of the powders obtained from differen natural products were mixed with $20 \mathrm{~g}$ of wheat seeds which did not receive any post-harvest treatment. Trials were repeated four times for each dose. Ten adults of Sitophilus granarius (L.) and Tribolium castaneum (Herbst) were introduced into each Petri dish and immediately closed. Dead insects were counted 7 days post-treatment.

\section{Germination tests of treated wheat seeds}

These tests were carried out to evaluate the effect of natural products on the germination of wheat seeds (Triticum aestivum) after 3, 6 and 12 month's period. A $200 \mathrm{~g}$ sample of seeds from each treatment was collected using a grain probe, labeled and placed in a small bag. 100 wheat seeds were collected at random and homogeneously deposited on paper impregnated with distilled water. These boxes were placed in climatic chambers regulated at a temperature of $20^{\circ} \mathrm{C}$.

\section{Data Analysis}

Statistical analyses were performed using analysis of variance ANOVA test followed by the Dunnett multiple comparison at the threshold of $\mathrm{p}=0.05$.

\section{RESULTS AND DISCUSSION}

\section{The rate of chemicals used by respondents in the Gharb area}

During the survey, it was found that nearly $56 \%$ of farmers produce and store their own seeds for planting in the next growing season. All surveyed producers keep their products in homes, stores and warehouses for a period ranging from three months to one year. The results obtained in this study revealed that respondents favor the use of synthetic insecticides compared to natural products with a proportion of $91 \%$ and $9 \%$, respectively. The reason behind this is to have better protection without losing quintals of harvested seeds (Figure 1).

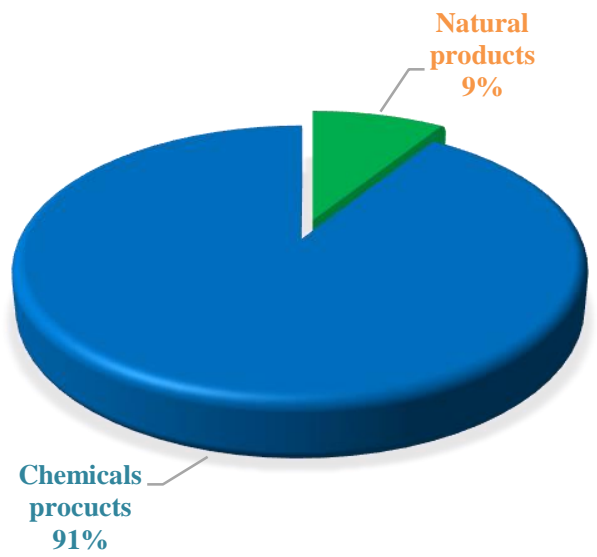

Figure 1: Rate of chemicals used by respondents.

The farmers interviewed during the survey agreed on the need to rely on traditional techniques and good practices rather than on chemical treatments that are dangerous to human health. A study was carried out at toxicology Unit of the Anti-Poison Center of Morocco and showed that the acute poisoning with pesticides represents $11,3 \%$ of all the cases of acute intoxication's (Rhalem et $a l ., 2009)$. The use of pesticidal plants that are available to farmers, and that can normally be used and handled safely, more than synthetic pesticides, has the dual benefit of being environmentally friendly and effective in pest control. (Rother, 2010; Stevenson et al., 2014; Mkenda et al., 2015).

\section{The conservation of seeds using the natural products}

In our survey, the treatments previously used by farmers, are very diverse; only cereals for self-consumption are treated with plants, allowing the seeds to retain their initial qualities for several months (Table 1). However, respondents expectations seem to vary according to the capacity of their stock, small farmers are attentive to the use of naturel products in ordre to reduce the loads, because the yields of cereal corps are moderate.

Table 1 Different plant used in this area study.

\begin{tabular}{|c|c|c|c|c|c|}
\hline $\begin{array}{l}\text { Scientific name } \\
\text { of the plant }\end{array}$ & $\begin{array}{c}\text { Part of the plant } \\
\text { used }\end{array}$ & Preparation & Targeted pests & Efficiency & Availability \\
\hline $\begin{array}{l}\text { Mentha } \\
\text { pulegium }\end{array}$ & Aerial part & $\begin{array}{l}\text { Apply dried leaves } \\
\text { on cereals }\end{array}$ & Several & Very effective & $\begin{array}{l}\text { Wild or farmed on } \\
\text { farms }\end{array}$ \\
\hline $\begin{array}{l}\text { Glycyrriza } \\
\text { foetida }\end{array}$ & Aerial part & $\begin{array}{l}\text { Apply dried leaves } \\
\text { on cereals }\end{array}$ & weevils & $\begin{array}{l}\text { Average } \\
\text { efficiency }\end{array}$ & Wild \\
\hline Allium sativum & Bulb & $\begin{array}{l}\text { Crush and mix } \\
\text { with the cereals }\end{array}$ & $\begin{array}{l}\text { Aphids, Weevils, } \\
\text { Tribulium }\end{array}$ & Effective & $\begin{array}{l}\text { Purchased from local } \\
\text { markets }\end{array}$ \\
\hline $\begin{array}{l}\text { Urginea } \\
\text { maritima }\end{array}$ & Bulb & $\begin{array}{l}\text { Cut in half and put } \\
\text { inside bags }\end{array}$ & Weevils, flies & $\begin{array}{l}\text { Average } \\
\text { efficiency }\end{array}$ & Limited knowledge \\
\hline $\begin{array}{l}\text { Capsicum } \\
\text { frutescens }\end{array}$ & $\begin{array}{l}\text { Peels of fruits and } \\
\text { seeds }\end{array}$ & Apply powder & $\begin{array}{l}\text { Weevils, } \\
\text { Tribulium }\end{array}$ & Effective & $\begin{array}{l}\text { Purchased from local } \\
\text { markets }\end{array}$ \\
\hline
\end{tabular}

This study showed that farmers in the three provinces: Kenitra, Sidi Kacem, Sidi Slimane use different traditional methods (ash, sand, aromatic plants) for the conservation of cereals and legumes (Figure 2). Some products such as rock salt are used to fill the inter-granular space. The use of salt is a traditional method to remove oxygen at a concentration of $1 \%(\mathrm{v} / \mathrm{v})$, Salt has the ability to scratch the cuticle insects, especially the primary pests that damage the seeds intact, allowing the larvae to develop inside the seeds (De Groot, 2004). 


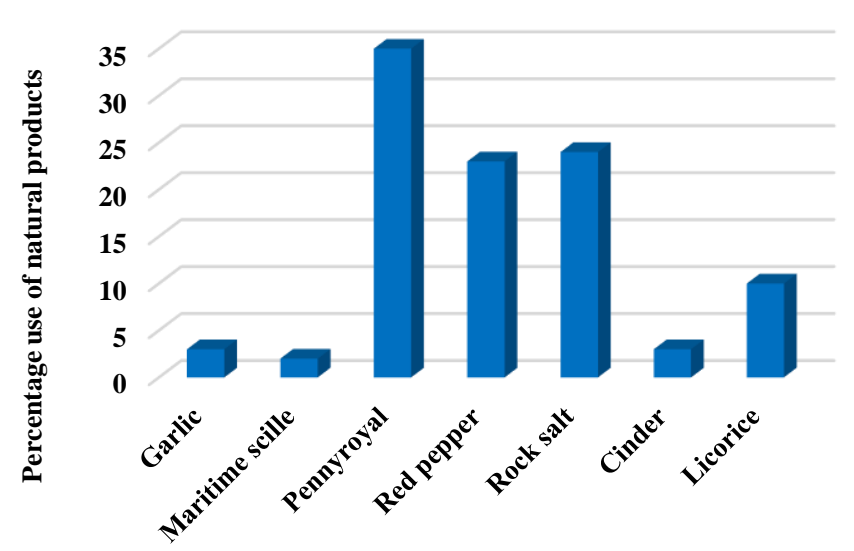

Figure 2 Percentage used of natural products for storing cereals and legumes by surveys

In the three provinces studied, some products used by farmers are the same throughout the area, such as rock salt, Capsicum frutescens and Mentha pulegium, with the exception of cinder, Urginea maritima and Glycyrriza foetida, which are used only by few people. Ashes act first and, if the infestation has already started, the effectiveness will be less (De Groot, 2004). In western Kenya, a study by Wambugu et al., (2009) found that cow dung ash, which is available for free on most farms, is a good protective agent for stored seeds.

Several preventive measures for a very long time have been tried by farmers to minimize the losses caused by pests of grains stocks. In tropical Africa and the South Pacific, papaya, banana, taro, ginger, breadfruit and heliconia leaves are used to store and preserve crops (Finau, \& Goodwillie, 1990). Mexico, Panama and Honduras small farmers have used the plant Gliricidia sepium to control preand post-harvest pests (Banoun, 1993).

Farmers in our study area also use plants (M. Pulegium, C. frutescens and $G$ foetida) to preserve seeds for their own consumption. These plants, which are locally available to farmers, cheaper and easier to use, have a strong odor that probably kills insects and inhibits their penetration into stocks. Some of the plant species produce compounds that negatively affect the growth and maturation of insects species (Grdiša \& Gršić, 2013).

Mushambanyi (2003) mentioned that farmers in Kivu (Democratic Republic of the Congo) felt that plant powders have few disadvantages for the seed that remains acceptable to taste, or for sale on the local market. A survey was carried out by other researchers in nine villages in the Hauts-Bassins of Burkina Faso, to diagnose farmers' perceptions of the post-harvest conservation of cowpea and groundnut, the results showed that producers keep their products with inert materials ash and sand (two volumes of ash for a volume of grains), as well as the use of pepper fruit (Capsicum frutenscens) and dry leaves of neem (Azadirachta indica) (Sankara et al., 2016).

\section{Toxicity by contact with natural products in grains}

In the course of our survey, the farmers estimated that insects are responsible for most of the post-harvest losses of cereals and legumes, especially the weevils, which is the most abundant species. The results illustrated in figure 3 and 4 showed the insecticidal effect of different natural products against adults of $S$. granarius and T. castaneum and indicated that the highest mortality percentage was recorded by M. pulegium powder compared with other natural products used. The difference in the responses of these products could be attributed to the influence of each product on the treated insects.

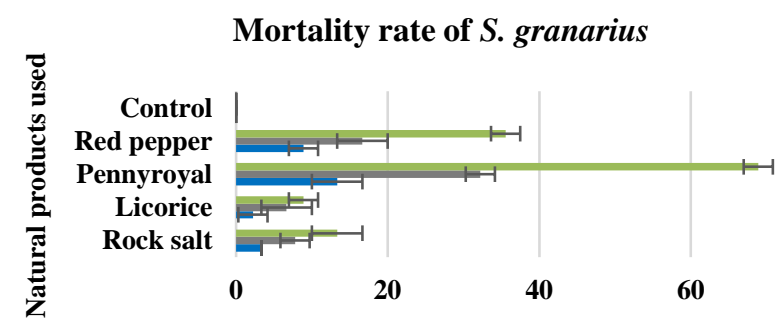

80

Concentrations: $-\mathbf{5 \%} \quad \mathbf{2 , 0 0 \%}$

Figure 3 Mortality of Sitophilus granarius according to the natural products used.

After 7 days of exposure, the 5\% dose of $M$. pulegium powder induces $69 \%$ and $57 \%$ mortality in $S$. granarius and in T. castaneum adults respectively. The adults of $S$. granarius were more sensitive to different concentrations of natural products used than T. castaneum adults. De Groot (2004) showed that dried mint green leaf powder protects chickpeas against colgrass, and $5 \mathrm{~g}$ of powder mixed with $1 \mathrm{~kg}$ of pea sufficient to kill $\pm 90 \%$ of bruch's in 48 hours. For rock salt and Glycyrrhiza foetida, none of the doses effectively controls weevils and triboliums. Mushambanyi (2003) who carried out a control test with insect repellant / insecticide-resistant Kivu plant powders, namely Maeasa lanceolata, Agava americana, and Tagetes minuta, and showed no dose of the plants used effectively controls weevils in sorghum stocks. Sorghum weight losses in stock were still in the order of $56-85 \%$.

\section{Mortality rate of $T$. castaneum}

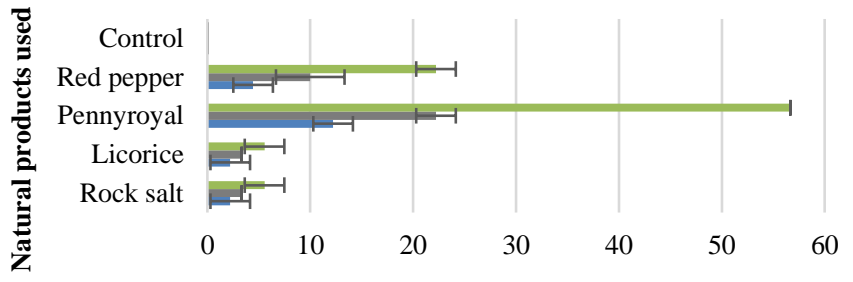

\section{Concentartions: $\square 5 \% \quad \square 2,00 \%$}

Figure 4 Mortality of Tribolium castaneum according to the natural products used.

In the present study, we chose the most used plants as insecticides against beetles' pests stock, and among the very old methods practiced even before the appearance of synthetic insecticides such as Capsicum frutescens. The most effective parts of the red pepper against insects are the peel of the fruit and the seeds used by the respondents as a preventive pest control.

Our results showed that Capsicum frutescens at a concentration of 5\% induced 22 $\%$ and $36 \%$ mortality on T. castaneum and S. granarius adults respectively. This plant was also used by the farmers of the Boukoko Commune (Central African Republic) for the protection of maize, groundnut and cowpea (Toumnou et al., 2012).

Evaluation of the toxicity of natural products on the germination of wheat seeds (Triticum aestivum)

A germination test was performed to determine the percentage of seeds that will germinate under favorable conditions and produce normal seedlings. Figure 5 shows the percentage of seeds sprouted as a function of different natural products was evaluated after 3,6 and 12 months.

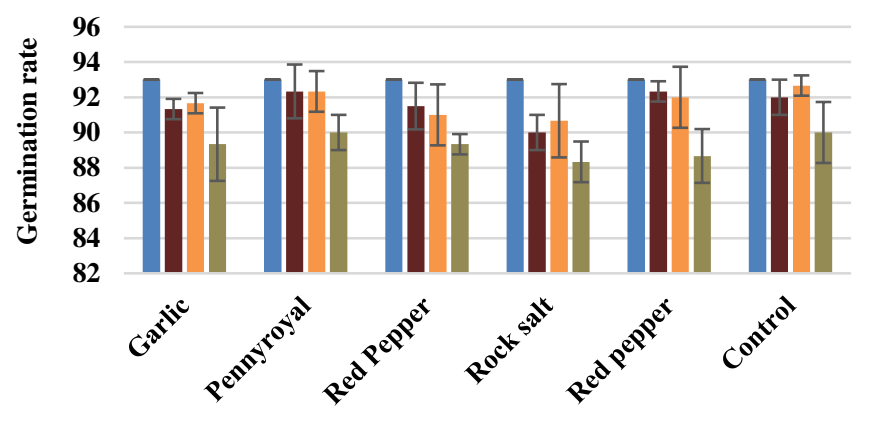

Times: $\quad$ T0 $\quad \mathbf{3}$ mois

Figure 5 Evaluation of the germination rate of wheat seeds in the laboratory conditions.

The results showed there were no significant differences in germination percentages in all groups treated with natural products compared to the control group. These natural products used by farmers for the protection of cereals against insect infestation have no effect on the germination of wheat seeds Results similar to ours have been reported by El idrissi et al. (2014), The essential oil of Dysphania ambrosioides strongly abolished the survival of adults of Sitophilus oryzae by fumigation without altering the germinability of treated durum wheat seeds.

\section{CONCLUSION}

We conclude that the results indicate a scientific justification for the use of these plants in the protection of cereals and legumes by farmers in the Gharb area of 
Morocco. But these alternative solutions remain well in place. These results should be disseminated to various actors who would need to accompany and advise them to use natural methods to preserve the quality of stored seeds.

\section{REFERENCE}

ABASS, A. B., NDUNGURU, G., MAMIRO, P., ALENKHE, B., MLINGI, N., BEKUNDA, M. 2014. Post-harvest food losses in a maize-based farming system of semi-arid savannah area of Tanzania. Journal of stored products research, 57 , 49-57. https://doi.org/10.1016/i.jspr.2013.12.004

ADJALIAN, E., NOUdOGBESSI, J., KOSSOU, D., SOHOUNHLOUE, D. 2014. Status and perspectives of struggle against Sitotroga cerealella (Olivier, 1789), pest of cereals in Benin: a short review. Journal of Applied Biosciences, 79(1), 6955-6967. http://dx.doi.org/10.4314/jab.v79i1.16

AMOABENG, B. W., GURR, G. M., GITAU, C. W., STEVENSON, P. C. 2014 Cost: benefit analysis of botanical insecticide use in cabbage: Implications for smallholder farmers in developing countries. Crop Protection, 57, 71-76. https://doi.org/10.1016/j.cropro.2013.11.019

ANJARWALLA P, BELMAIN S, SOLA P, JAMNADASS R, STEVENSON PC. 2016. Guide des plantes pesticides. World Agroforestry Centre (ICRAF), Nairobi, Kenya.

BANOUN, F. 1993. Rat-killer extraordinaire. Ceres, 25(2), 9-10.

BENHALIMA, H., CHAUDHRY, M. Q., MILLS, K. A., PRICE, N. R. 2004 Phosphine resistance in stored-product insects collected from various grain storage facilities in Morocco. Journal of Stored Products Research, 40(3), 241249. https://doi.org/10.1016/S0022-474X(03)00012-2

DE GROOT, I. 2004. AD18F Protection des céréales et des légumineuses stockées. Agromisa Foundation.

DE VRIES, F. P. 2001. Food security we are losing ground fast. Crop science: Progress and prospects, 1-14.

EL IDRISSI, M. \& AMECHROUQ, A. 2014. Study of the insecticidal activity of the essential oil of Dysphania ambrosioïdes L.(Chenopodiaceae) on Sitophilus oryzae (Coleoptera: Curculionidae) J. Mater. Environ. Sci. 5 (4) 989-994 https://www.researchgate.net/publication/263182425.

FINAU, S.A. GOODWILLIE, D. 1990. Storing and Preserving Pacific lsland Foods. The

GATIGNOL, C., ETIENNE, J. C. 2010. Pesticides et santé. Rapport parlementaire. Office parlementaire d'évaluation des choix scientifiques et technologiques. Rapport, (2463).

GRDIŠA, M. GRŠIĆ, K. 2013. Botanical insecticides in plant protection. Agriculturae Conspectus Scientificus, 78(2), 85-93. https://hrcak.srce.hr/104637 GUĖYE, M. T., SECK, D., WATHELET, J. P., LOGNAY, G. 2011. Controlling pests of cereals and legumes in Senegal and West Africa: a review. Biotechnologie, Agronomie, Société et Environnement= Biotechnology, Agronomy, Society and Environment, 15(1), 183-194. http://hdl.handle.net/2268/89355

HAUBRUGE, E., SCHIFFERS, B., GABRIEL, E., VERSTRAETEN, C. 1988 Etude de la relation Dose-Efficacité de six insecticides à l'égard de Sitophilus granarius L., S. oryzae L. et S. zeamais Mots.(Coleoptera, Curculionidae). Med. Fac. Landbouw Rijksuniv. Gent, 719-726

HEDJAL, M. 2014. Identification des principes actifs des huiles essencielles de quelques résineux plantes aromatiques de provenance algérienne et tunisienne : Etude de leurs activités biologiques à l'égard d'un insecte ravageur des graines stockées, callosobruichus maculatus F. 1775 (Coleoptera: Bruchidae) (Doctoral dissertation, Universite Mouloud Mammeri).

HODGES, R. J., MARITIME, C. 2012. Postharvest weight losses of cereal grains in Sub-Saharan Africa. Natural Resources Institute, University of Greenwich, 24. HUIGNARD, J., GLITHO, I. A., MONGE, J. P., REGNAULT-ROGER, C. 2011. Insectes ravageurs des graines de légumineuses : Biologie des Bruchinae et lutte raisonnée en Afrique. Editions Quae.

MKENDA, P., MWANAUTA, R., STEVENSON, P.C., NDAKIDEMI, P., MTEI, K. BELMAIN, S.R. 2015. Extracts from field margin weeds provide economically viable and environmentally benign pest control compared to synthetic pesticides. PLOS ONE. 10(11): e0143530. https://doi.org/10.1371/journal.pone.0143530

MULTIGNER, L. 2005. Effets retardés des pesticides sur la santé humaine. Environnement, Risques \& Santé, 4(3), 187-194.

MUSHAMBANYI, T. M. B. 2003. Effet de différentes poudres végétales sur l'infestation des semences de légumineuses et de céréales au cours de la conservation au Kivu (République démocratique du Congo). Cahiers Agricultures, 12(1), 23-31.

NGAMO, L. S. T., HANCE, T. H. 2007. Diversité des ravageurs des denrées et méthodes alternatives de lutte en milieu tropical. Tropicultura, 25(4), 215-220.

OBENG-OFORI, D. 2011. Protecting grain from insect pest infestations in Africa: producer perceptions and practices. Stewart Postharvest Rev, 3(10).

OUEDRAOGO, I., SAWADOGO, A., NEBIE, R. C., DAKOUO, D. 2016 Evaluation of the toxicity of essential oils of Cymbopogon nardus (L) and Ocimum gratissimum (L) against maize insects Sitophilius zeamais Motsch and Rhyzopertha dominica F, the major insect pests in maize storage in Burkina Faso.
International Journal of Biological and Chemical Sciences, 10(2), 695-705. http://dx.doi.org/10.4314/ijbcs.v10i2.20

PLUKE H. R. W., PERMAUL D., LEIBEE G. L. 1999. Integrated Pest Management and the Use of Botanicals in Guyana, Inter Americal Institute for Cooperation on Agriculture, Georgetown, Guyana, South America, 77.

REDLINGER, L. M., ZETTLER, L. J., DAVIS, R., SIMONAITIS, R. A. 1988 Evaluation of pirimiphos-methyl as a protectant for export grain. Journal of economic entomology, 81(2), 718-721. https://doi.org/10.1093/jee/81.2.718

RHALEM, N., KHATTABI, A., ACHOUR, S., SOULAYMANI, A., BENCHEIKH, R. S. 2009. Facteurs prédictifs de gravité de l'intoxication aux pesticides. Expérience du Centre Antipoison du Maroc. In Annales de Toxicologie Analytique 21(2), 79-84. EDP Sciences.

ROTHER, H. A. 2010. Falling through the regulatory cracks: street selling of pesticides and poisoning among urban youth in South Africa. International journal of occupational and environmental health, 16(2), 183-194. http://dx.doi.org/10.1051/ata/2009039

SANKARA, F., GONDE, Z., SANOU, A. G., SOMDA, I. 2016. Diagnostic participatif des pratiques paysannes post-récolte et des contraintes de stockage de deux légumineuses cultivées dans la région des Hauts-Bassins du Burkina: cas du niébé, Vigna unguiculata (L.) Walp. et du voandzou (Vigna subterranea (L.) Verdc./[Participatory analysis of farmers' post-harvest practices and storage constraints of both legumes grown in the Hauts-Bassins region of Burkina Faso: cases of cowpea, Vigna unguiculata (L.) Walp. and Bambara groundnut, Vigna subterranea (L.) Verdc.]. International Journal of Innovation and Applied Studies, 16(3), 646

South Pacific Community Training Project. Quality Prints, Suva, Fiji, pp. 41-92. STEVENSON, P.C., ARNOLD, S.E.J. BELMAIN, S.R. 2014. Pesticidal plants for stored product pest in smallholder farming in Africa. In "Advances in Plant Biopesticides" Ed. D. Singh. Springer Verlag.

TOUMNOU, A. L., SECK, D., NAMKOSSERENA, S., CISSE, N KANDIOURA, N., SEMBENE, M. 2012. Utilisation des plantes indigènes à effet insecticide pour la protection des denrées stockées contre des insectes ravageurs à Boukoko (Centrafrique). International Journal of Biological and Chemical Sciences, 6(3), 1040-1050. http://dx.doi.org/10.4314/ijbcs.v6i3.11

WAMBUGU, P. W., MATHENGE, P. W., AUMA, E. O., VAN RHEENEN, H. A. 2009. Efficacy of traditional maize (Zea mays L.) seed storage methods in western Kenya. African Journal of Food, Agriculture, Nutrition and Development, 9(4).

WORLD BANK, FAO, NRI, 2011. Missing Food: the Case of Post-harvest Grain Losses in Sub-Saharan Africa. In: Economic Sector Work Report No. 60371AFR. World Bank, Washington, DC 